\title{
PRELIMINARY PHYTOCHEMICAL SCREENING OF THE TOTAL AND SUCCESSIVE EXTRACTS OF TRIUMFETTA FLAVESCENS HOCHST GROWING IN EGYPT
}

\author{
El-Ahmady, Sherwet, H. $^{(1)}$; Lotfy, Rehab, A. ${ }^{(2)}$ and Ahmed, Mai, M. ${ }^{(2)}$
}

1) Faculty of Pharmacy, Ain Shams University 2) Natural Product Unit, Desert Research Center

\begin{abstract}
The preliminary phytochemical screening of Triumfetta Flavescens revealed the presence of flavonoids, alkaloids, tannins, terpenoids and sterols, carbohydrates, saponins, glycosydes, protein and amino acids, cardiac glycosides, coumarins and resins and absence of anthraquinones.

The percentage yields of the successive extracts were also determined and showed that the highest percentage was in methanol fraction $(8.36 \%)$ while the lowest one was in ethyl acetate fraction $(0.92 \%)$.

Keywords: Phytochemical screening, Successive extraction, Triumfetta flavescens.

\section{INTRODUCTION}

The value of medicinal plants in drug discovery is known to us well and the human being used them for various purposes from the beginning of the human history (Farnsworth, 2008). Traditional folk remedies from plants have always guided scientists to search for new medications in order to maintain and promote healthy life for human and animals (Hosseinzadeh, 2015).

Triumfetta flavescens belongs to the family Tiliaceae. The genus Triumfetta includes about 200 species which are widespread all over the world. It's characterized by densely stellate-hair. Leaves alternate reducing in size up
\end{abstract}


inflorescence and Flowers often forming interrupted panicles (Halford, 1997). It is a perennial shrub $0.5-1.2 \mathrm{~m}$ height, much-branched from the base with pale yellow flowers on both sides to greenish yellow above and whitish below (Boulos, 2000).

Triumfetta flavescens presents in Saudi Arabia, Sudan, Ethiopia, and south Egypt in Gebel Elba region. The number of species present in Egypt is two which are Triumfetta flavescens and Triumfetta rhomboidea (Täckholm, 1956).

The antimicrobial tests showed a mild activity against Echerichia coli and Enterococcus hirae (Mevy et al., 2006).

Phytochemical screening is one of the techniques to identify new sources of therapeutically and industrially important compounds like alkaloids, flavonoids, phenolics, steroids, tannins, saponins etc. present in the plant extracts. These compounds can be derived from any part of the plants like bark, leaves, flowers, seeds. Knowledge of the chemical constituents of plants is desirable because such information will be of value for the synthesis of new bioactive compound/s for treating the specific disease.

\section{MATERIALS AND METHODS}

Plant Material: Aerial parts of Triumfetta flavescens were collected in January 2016 from Gebel Elba region south east Egypt. The plant was dried in the shade at room temperature until it became well dried. After drying, the plant materials were ground and kept in a well closed container for further investigation. 


\section{Preparation of the extracts:}

a) Total extract: Triumfetta flavescens aerial parts (100 gm) was extracted with $70 \%$ ethanol for 12 hours using maceration. The extract was evaporated to dryness using rotary evaporator. The weight of the residual extract was estimated.

B) Successive extracts: Using soxhlet apparatus 50 gram Triumfetta flavescens aerial parts powder was extracted using petroleum ether, chloroform, ethyl acetate, methanol, methanol $50 \%$ and water.

The extracts obtained using solvents were concentrated using rotary vacuum evaporator and then dried and percentage yield was determined.

\section{Preliminary phytochemical Screening:}

Preliminary phytochemical Screening was carried out on the total extract and the successive extracts as follow:

The total and successive extracts were subjected to preliminary screening for carbohydrates and/or glycosides (Harper, 1975) and (Balbaa et al., 1981), tannins (Balbaa et al., 1981), flavonoids (Shinoda, 1928), alkaloids (Woo et al., 1977), sterols and/or triterpenes (Brieskorn and Klinger-Hand, 1961), saponins (Wall et al., 1954), anthraquinones (Balbaa, 1986), proteins and/or amino acids and polypeptides (Plimmer, 1926) and (Coutts and Snail, 1966), cardiac glycosides (Balba, 1986), resins (Balbaa, 1986), coumarins (Farnsworth, 1966).

\section{RESULTS AND DISSCUSSION}

Preliminary phytochemical screening revealed the presence of alkaloids, flavonoids, tannins, triterpenoids and sterols, carbohydrates, saponins, 
glycosides, protein and amino acids, cardiac glycosides, coumarins and resins and absence of anthraquinones as shown in table (1).

Table 1: Preliminary phytochemical screening of the total extract of Triumfetta flavescens aerial parts

\begin{tabular}{|c|c|}
\hline Chemical Test & Result \\
\hline Alkaloid & $+\mathrm{ve}$ \\
\hline Flavonoid & $+\mathrm{ve}$ \\
\hline Tannin & $+\mathrm{ve}$ \\
\hline Triterpenoids and Sterols & $+\mathrm{ve}$ \\
\hline Carbohydrates & $+\mathrm{ve}$ \\
\hline Saponins & $+\mathrm{ve}$ \\
\hline Glycosides & $+\mathrm{ve}$ \\
\hline Protein \& amino acids & $+\mathrm{ve}$ \\
\hline Anthraquinone & $-\mathrm{ve}$ \\
\hline Cardiac glycosides & $+\mathrm{ve}$ \\
\hline Coumarins & $+\mathrm{ve}$ \\
\hline Resin & $+\mathrm{ve}$ \\
\hline
\end{tabular}

The yield of successive extracts has shown in table (2) and revealed that highest yield percent was methanol fraction $(8.36 \%)$ and the lowest concentration was ethyl acetate $(0.922 \%)$.

Table 2: The yield percentage of total extract and different fractions of Triumfetta flavescens aerial parts.

\begin{tabular}{|c|c|}
\hline Sample & Yield Percentage (\%) \\
\hline Petroleum ether & 2.026 \\
\hline Chloroform & 1.386 \\
\hline Ethyl acetate & 0.922 \\
\hline Methanol & $8.36 \cdot$ \\
\hline Methanol 50\% & 6.364 \\
\hline Water & 0.973 \\
\hline
\end{tabular}


The phytochemical evaluation of various phytoconstituents in successive extracts of the aerial parts of Triumfetta flavescens were evaluated. Out of these extracts methanolic extract showed maximum number of plant constituents such as flavonoids, alkaloids, phenol, tannins, steroids, sterols, coumarins, carbohydrate, glycosides, protein and amino acids and saponins. The results are presented in table (3).

Table 3: Phytochemical screening of the successive extracts of aerial parts of Triumfetta flavescens.

\begin{tabular}{|c|c|c|c|c|c|c|}
\hline \multirow[b]{2}{*}{$\begin{array}{c}\text { Plant } \\
\text { Constituent }\end{array}$} & \multicolumn{6}{|c|}{ Extracts } \\
\hline & $\begin{array}{c}\text { Petroleum } \\
\text { Ether } \\
\text { Extract }\end{array}$ & $\begin{array}{l}\text { Chlorofom } \\
\text { Extract }\end{array}$ & $\begin{array}{c}\text { Ethyl } \\
\text { Acetate } \\
\text { Extract }\end{array}$ & $\begin{array}{l}\text { Methanol } \\
\text { Extract }\end{array}$ & $\begin{array}{c}\text { Methanol } \\
50 \% \\
\text { Extract }\end{array}$ & $\begin{array}{c}\text { Aqueous } \\
\text { Extract }\end{array}$ \\
\hline 1) Alkaloids & - ve & +ve & - ve & $-\mathrm{ve}$ & -ve & -ve \\
\hline 2) Flavonoids & -ve & -ve & +ve & +ve & +ve & +ve \\
\hline 3) Tannins & -ve & -ve & +ve & +ve & +ve & +ve \\
\hline $\begin{array}{l}\text { 4) Triterpenoids\& } \\
\text { Sterols }\end{array}$ & +ve & -ve & - ve & -ve & -ve & -ve \\
\hline 5) Carbohydrates & -ve & -ve & -ve & $+v e$ & + ve & -ve \\
\hline 6) Saponins & -ve & -ve & -ve & $+\mathrm{ve}$ & $+\mathrm{ve}$ & $+v e$ \\
\hline 7) Glycosides & +ve & -ve & -ve & +ve & +ve & -ve \\
\hline $\begin{array}{l}\text { 8) Protein\& amino } \\
\text { acids }\end{array}$ & $+\mathrm{ve}$ & +ve & $+\mathrm{ve}$ & $+\mathrm{ve}$ & $+\mathrm{ve}$ & $+\mathrm{ve}$ \\
\hline 9) Anthraquinone & -ve & -ve & -ve & -ve & -ve & -ve \\
\hline $\begin{array}{l}\text { 10) Cardiac } \\
\text { glycosides }\end{array}$ & -ve & -ve & -ve & $+\mathrm{ve}$ & $+\mathrm{ve}$ & -ve \\
\hline 11) Coumarins & -ve & $+v e$ & $+v e$ & $+v e$ & $+v e$ & $+v e$ \\
\hline 12) Resins & +ve & +ve & -ve & -ve & -ve & -ve \\
\hline
\end{tabular}

+ ve $\rightarrow$ Present

-ve $\rightarrow$ Abscent 
J. Environ. Sci.

Institute of Environmental Studies and Research - Ain Shams University

\section{CONCLUSION}

The results obtained in the present study indicates aerial parts of Triumfetta flavescens have the potential to act as a source of useful drugs because of presence of various phytochemical components such as carbohydrate, protein, lipids, phenols, flavonoids and tannin. The results are very much encouraging but scientific validation is necessary before being put into practice.

It is recommended to do further investigations on the phytochemical constituents and biological activity of this plant because it is rich in the active materials.

\section{REFERENCES}

Balbaa, S.I. (1986): Chemistry of crude drugs, Laboratory manual, Fac. Of Pharm. Cairo Univ. pp. 195.

Balbaa, S.I.; Hilal, S. H. and Zaki, A. Y. (1981): Medicinal plants constituents, 3 rd ed. General Organization of University Books, Cairo, Egypt, pp. 644.

Boulos L. (2000): Flora of Egypt, Al-Hadra publishing, Cairo, Egypt, volume two: pp.91.

Brieskorn, C.H. and Klinger-Hand, P.W. (1961). Triterpenes and sterols in leaves of Salvia triloba and Pyrus malus. Arch. Pharm, 294, 380391.

Coutts, R. T. and Snail, G.A. (1966): Polysaccharides, peptides and proteins ,William Heinemann Medical book Ltd., London, p. 94.

Fransworth, N.R. (1966). Biological and Phytochemical Screening of Plants. J. of Pharm. Sci., 55, 225. [cited from Abd El-Shafek, K.A (1997) M.Sc. Thesis, Chemical studies on certain plants of Family Labiatae. Faculty of Science, Cairo University. 174pp.]. 
Farnsworth N.R. (2008): The role of ethnopharmacology in drug development, Bioactive compounds from plants. John Wiley \& Sons. A WileyInternational Publication. pp. 2-11.

Halford, D.A. (1997): Notes on Tiliaceae in Australia, 3: A revision of the genus Triumfetta L. Austrobaileya, 4.pp. 495-587.

Harper, H.A. (1975): Review of Physiological Chemistry, $15^{\text {th }}$ ed. Long Medicinal Publications, Los Angeles, Califoria, p. 570.

Hosseinzadeh, S.; Jafarikukhdan, A.; Hosseini, A.; Armand, R. (2015). The Application of Medicinal Plants in Traditional and Modern Medicine: A Review of Thymus vulgaris. International Journal of Clinical Medicine, 6, pp. 635-642

Mevy, J. P.; Bessiere, J.M.; Rabier, J.; Dherbomez, M.; Ruzzier, M.; Millogo, J. and viano, J. (2006). Composition and antimicrobial activities of the essential oil of Triumfetta rhomboidea Jacq. Flavour Frag J, 21(1), 80-83.

Plimmer, R. H. A. (1926): Practical organic and biochemistry, Longmans Greeb and Co. Ltd, New York, 25, pp. 371.

Shinoda, I. (1928). Color reaction of flavone and flavonol derivatives and the like. J. Pharm. Soc. Japan, 48, 214-220.

Täckholm V., (1956): Student's flora of Egypt, Second edition, published by Cairo University, Egypt, p.234.

Wall, M. E.; Kreider, M. M.; Kremson, C. F.; Eddy, C. R.; Williaman J. J.; Corell, D. S. and Gentry, H. S. (1954). Steroidal sapogenins and other constituents. J. Pharm. Soc., 43, 1-3.

Woo, W. S.; Chi, H. J. and Yun, H. S. (1977). Alkaloid screening of some Saudi Arabian plant. Kor. J. Pharmacog., 8 (3), 109-113. 


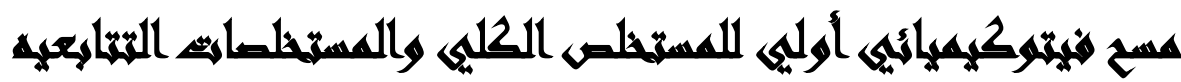

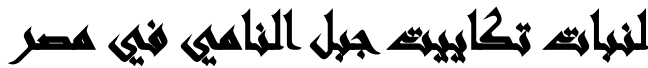

[६]

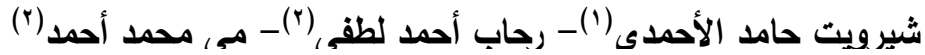

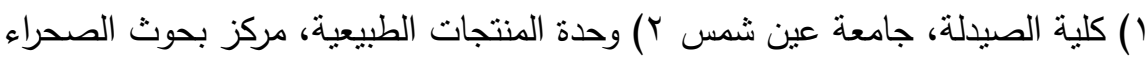

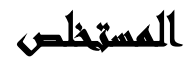

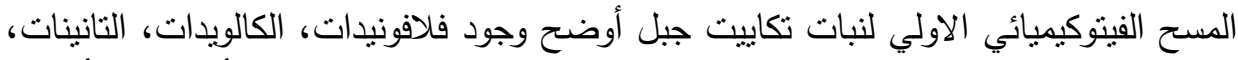

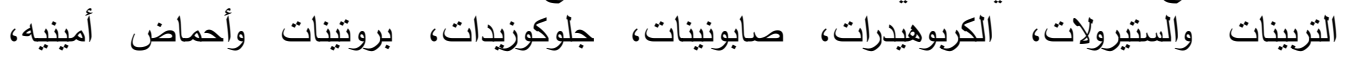$$
\text { جلوكوزيدات قلبيه، كومارينات و راتينجات. وخلو النبات من الأنثراكينونات. }
$$

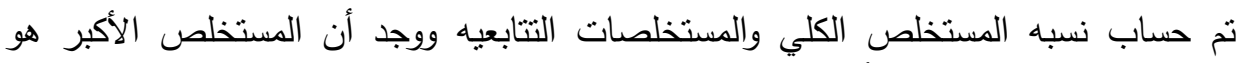

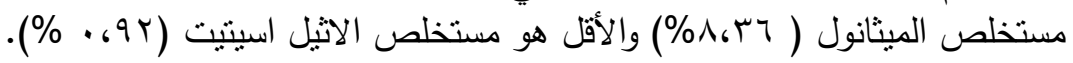

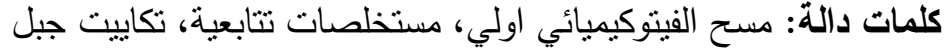

